УДК 343.631(477+100)

DOI https://doi.org/10.32837/apdp.v0i90.3219

А. С. Романова, П. В. Чернявський, І. О. Соколова

\title{
ВІДПОВІДАЛЬНІСТЬ ЗА НАКЛЕП (ДИФАМАЦІЮ) В УКРАЇНI ТА КРАЇНАХ СВІТУ
}

Проблема дифамації, її нормативного оформлення, доведення й боротьби з нею у вітчизняному й зарубіжному науковому дискурсі була і є актуальною для розгляду. Незважаючи на те, що законодавчо термін «дифамація» в Україні не закріплено, останнім часом це явище все частіше зустрічається в українському суспільстві та становить загрозу її демократичному ладу.

У статті проаналізовано останні концептуальні підходи до розуміння поняття дифамації у світі та зокрема в Україні. Досліджено та висвітлено останні зміни в українському законодавстві стосовно наклепу та відповідальності громадян за його вчинення.

Метою статті є дослідження відповідальності за наклеп та дифамацію, станом на сьогодні у різних країнах світу та в нашій із вами Батьківщині-Україні.

Об’єктивність, достовірність подачі інформації, соціальна відповідальність є одними з найважливіших принципів, яких повинні дотримуватися громадяни. Однак не завжди про них пам'ятають, а навпаки починають публікувати і поширювати інформацію, яка не відповідає дійсності, тобто є відвертим наклепом.

Дифама́ція ( від лат. diffamare = поширювати плітки) - поширення про особу неправдивої інформації, яка принижує їі честь та гідність, завдає шкоди діловій репутації. Дифамація є синонімом до терміну наклеп, тобто «приниження честі, гідності та ділової репутації». Загалом, українське законодавство не вживає термін дифамація, однак як лаконічне змістовне слово іншомовного походження він активно використовується на практиці та в законодавствах деяких інших країн.

Будь-який факт може вважатись дифамацією лише за умови: 1) неправдивості, 2) оперування фактичними даними, 3) шкідливості, 4) завданню збитків репутації конкретної особи, тобто це означає, що заперечуване твердження було прочитане, почуте або побачене іншими особами.

Переважно дифамацію розрізняють у писемній (наклеп) та усній формі (лихослів'я, обмовляння). Зважаючи на те, що друковане слово зазнає більшого поширення, наклеп вважають більш серйозним проступком. Але останнім часом висловлювання оприлюднені через радіо та телебачення також прирівнюють до наклепу, в зв'язку з поширенням впливу цих засобів масової інформації.

Норми дифамаційного права є у багатьох країнах як континентальної, так і англосаксонської системи права. Наприклад, у Франції захист честі, гідності та репутації регулюється Актом про друк 1881 р., в якому закріплені правила відповідальності за дифамацію у двох формах - наклепу та образи (ст. 29), а у Великій Британії діє Закон про дифамацію 1996 р. Закон з такою ж назвою діє і в Сінгапурі з 1965 року. 
Найбільш досконало захист честі, гідності та репутації врегульовано в США, де існують цілі галузі права: дифамаційне право та дифамаційний процес. Але загального закону, який би регулював судовий процес щодо дифамації немає, оскільки загальна система права побудована на прецедентах. У багатьох країнах наклеп відносять і до цивільного правопорушення, і до кримінального.

Законодавством багатьох держав в усьому світі дифамацію визначено як злочин. У кримінально-правовому розумінні цим явищем, як правило, вважаються бездоказові твердження чи поширення фактів, які паплюжать репутацію.

Кримінальна відповідальність за дифамацію передбачена кримінальними кодексами таких європейських держав, як Австрія (ст. 111), Бельгія (глава V Кримінального кодексу), Італія (ст. 595), Португалія (ст. 180), Хорватія (ст. 199, 199-2, 200-1, 200-2), Фінляндія (глава 24, ст. 9, 10), Данія (ст. 267), Норвегія (глава 23, ст. 246, 247, 248), Бразилія (ст. 139).

Кримінальне законодавство про наклеп перестало застосовуватися в США в 1950-ті роки (і було б сьогодні визнане неконституційним, крім тих норм, що застосовуються до заяв, здатних спричинити порушення суспільного порядку). У Великій Британії норми, пов'язані з наклепом, залишаються частиною загального права і фактично не використовуються в останні роки.

Дедалі частіше законодавство, що карає за дифамацію в кримінальному порядку, розглядається як таке, що невиправдано обмежує свободу слова, в більшості демократичних країн такі закони застосовуються вкрай рідко або не застосовуються взагалі. Протягом кількох останніх років у низці держав ухвалили рішення про скасування кримінальних санкцій за дифамацію. Серед таких країн Велика Британія та Ірландія, Гана, Боснія і Герцеговина, Естонія, Грузія, Україна та інші.

Розгляньмо, яка відповідальність за наклеп застосовується у різних країнах. У різних штатах США законодавство має деякі відмінності. Покарання за наклеп може доходити до 250 тис. доларів штрафу або 10 років позбавлення волі. Якщо в одних штатах 3MI, яке розповсюдило наклеп, несе відповідальність разом з безпосереднім джерелом, то в інших штатах до відповідальності не притягуються. Також бувають випадки, коли виникає групове звинувачення і групова відповідальність. Кримінальні кодекси 19 штатів США містять кримінальну відповідальність за дифамацію. В деяких штатах США кримінальні наслідки дифамації можуть бути досить суворими, наприклад, в Колорадо кримінальне покарання за наклеп тривалий час було пов'язано з тюремним ув'язненням терміном до 18 місяців і штрафом в розмірі 100,00 доларів за перше порушення. Закон про наклеп (libel law) був досить широким: було злочином «свідомо публікувати або поширювати, використовуючи письмовий інструмент, підпис, зображення тощо, будь-яку заяву або предмет, спрямовані на заплямування пам'яті загиблого, або на заплямування його честі, гідності, та ділової репутації, або на викриття. Також виділяють систему правового регулювання діяльності ЗМІ в США. яку можна поділити на кілька груп: перша група - це свобода самовираження; друга група - відповідальність 3МІ за поширення сумнівної, образливою або недостовірної інформації, що порочить честь і гідність людини, що підриває її особисту або ділову репутацію; третя група - права і обов’язки ЗМІ з позицій державної (національної) без- 
пеки; четверта група - можливість журналістів захищати свої джерела інформації; п’ята група - питання контролю і регулювання засобів масової інформації з боку державних органів.

Розгляньмо ще й інші країни в аспекті кримінальної відповідальності за скоєння дифамації.

Законодавством Франиї відповідальність за дифамацію закріплена в Акті про пресу 1881 р.: «Будь-яке твердження або звинувачення у факті, що завдає шкоди честі чи репутації особи або групи осіб, якій приписується факт, є дифамацією. Безпосередня публікація чи шляхом відтворення такого твердження чи такого звинувачення карається, навіть якщо воно зроблене у формі, що виражає сумнів чи якщо воно стосується особи чи групи осіб, чиї імена прямо не названі, але ідентифікація яких можлива через мовлення, виголоси, погрози, викладені у письмовому чи друкованому вигляді, злочинні плакати чи афіші» Також за наклеп можна поплатитися не тільки штрафом аж до 45 тис. євро або тюремним строком до п’яти років, а й забороною займатися певними видами професійної діяльності.

Стаття 186 Кримінального кодексу Німеччини встановлює відповідальність особи, «...яка стверджує чи розповсюджує факт, пов’язаний з іншою особою, що може опорочити її чи негативно вплинути на громадську думку про неї, якщо тільки неможна довести, що цей факт правдивий», у вигляді позбавлення волі до двох років, а ст. 188 передбачає санкцію за дифамацію осіб, які займаються політичною діяльністю: «Якщо злочин дифамації вчинено публічно, на зустрічі або через розповсюдження письмових матеріалів стосовно особи, яка задіяна у широковідоме політичне життя на основі позиції цієї особи в публічному житті, та якщо злочин може суттєво ускладнити її громадську діяльність, покаранням має бути ув'язнення від трьох місяців до п'яти років». А ще у Німеччині існує поняття, як наклеп проти чинної влади, її образу чи заклики до порушення цілісності республіки. Покарати за це можуть великим штрафом або позбавленням волі до п'яти років. Ті, хто в публічному виступі, на зборах або за допомогою письмових матеріалів поширюють зневагу проти персони, що грає роль в політичному житті народу, за мотивами, які справляють вплив на стан ображати особи в суспільному житті, і якщо діяння спрямоване на те, щоб істотно ускладнити громадську діяльність даного політичного діяча, караються позбавленням волі на строк від трьох місяців до п'яти років.

Глава 5 Кримінального кодексу Швецї̈ визначає, що особі, яка називає іншу особу злочинцем чи зазначає, що особа веде спосіб життя, який вартий осуду, або іншим чином надає інформацію з наміром розголосу, щоб викликати зневагу інших, присуджується штраф за дифамацію, а груба дифамація карається штрафом чи позбавленням волі до двох років» А ще у законодавстві цієї держави розрізняють дві форми наклепу - саме наклеп, або дискредитація чи образу людини. Якщо перша форма наклепу іноді стає приводом для вчинення юридичних дій проти 3МI, то друга являє собою в основному особисті образи «віч-на-віч» і рідко служить підставою для скарг на пресу.

Стаття 212 Кримінального кодексу Польщі визначає, що той, хто приписує особі, групі осіб, інституції чи організаційній одиниці, що не має статусу юридичної 
особи, таку поведінку чи характеристику, що може дискредитувати їх в очах громадської думки або призвести до втрати довіри, необхідної для даної посади, професії чи роду діяльності, підлягає сплаті штрафу, покаранню у вигляді обмеження свободи чи покаранню у вигляді позбавлення свободи до одного року. Якщо зловмисник учиняє діяння через ЗМІ, він підлягає сплаті штрафу, покаранню у вигляді обмеження свободи чи покаранню у вигляді позбавлення свободи до двох років» .

Кримінальним кодексом Албанії за образу посадових осіб (ст. 239) передбачено максимальне покарання до двох років ув'язнення, а за умисну дифамацію Президента Республіки передбачено покарання до трьох років позбавлення волі (ст. 241).

У Республіці Чехіл ст. 184 Кримінального кодексу визначено дифамацію злочину, а ст. 184-1 передбачено ув'язнення до одного року, а у випадку використання преси, телебачення, радіо та інших мереж - до двох років.

У Південній Кореї за дифамацію передбачено покарання до семи років позбавлення волі.

Наклеп є кримінальним злочином в Бельгії, але цей злочин розглядається вкрай рідко, оскільки неправдиві висловлювання є «злочином преси», яка відповідно до статті 150 Конституції Бельгії має оцінюватися в суді присяжних. Згідно статті 443 Кримінального кодексу кримінальне переслідування за наклеп визначено як «зловмисне і публічне приписування цій особі факту, доведеного або недоведеного в судовому порядку і здатного зганьбити честь і гідність вказаної особи або накликати на нього суспільне презирство». Покарання буває у вигляді штрафу або тюремного ув'язнення.

Засоби масової інформації Норвегї мають відносно високий рівень свободи. У Кримінальному кодексі цієї країни є кілька статей про захист репутації державних інститутів, апосадові особи мають можливість подати цивільний позов або порушити кримінальну справу з публічним звинуваченням у відповідності з цими положеннями. Згідно зі статтею 130 КК, будь-яка людина, що подала неправдиве повідомлення про дії влади, може бути піддана штрафу або тюремному ув'язненню на термін до одного року. Якщо ж заява мала на меті «завдання шкоди репутації влади», в цьому випадку карається навіть необережне поводження. Ці положення давно не застосовувалися, але вони все ж не скасовані. Публічна образа чи наклеп караються 2 роками позбавлення волі або штрафом від 1000 до 2000 євро. Законодавство поділяє покарання за наклеп і образу, що з'явилося в будь-якому ЗМІ. Так, в цьому випадку накладається штраф у понад 500 євро або від 6 місяців до трьох років ув'язнення.

У Великобританї̈ наклеп розцінюється як «злочин проти громадського порядку». У країні є чотири види наклепу: богохульство, дифамаційний пасквіль (наклепницька стаття в 3МI), непристойний пасквіль і пасквіль (розповсюджуваний в бунтівних цілях). Як покарання передбачені адміністративне стягнення або позбавлення волі.

Що ж стосується нашої країни, то щоб простежити, наскільки довгий шлях в праві України пройшли поняття наклепу і розповсюдження неправдивої інформації, повернемося на декілька років назад.

Одним 3 найбільш цікавих та досить суперечливих введень в правову систему був Закон України «Про судоустрій і статус суддів» та процесуальних законів щодо 
додаткових заходів захисту безпеки громадян від 16 січня 2014 року № 721-VII. Так як об’єктом дослідження цієї статті є таке явище як наклеп та розповсюдження неправдивої інформації, то найбільше уваги приділімо змінам, які Верховна Рада України внесла цим законом саме до Кримінального кодексу України.

Однією з головних цілей прийняття цього закону є забезпечення та охорону кожної людини права на захист та повагу її честі та гідності не залежно від ї̈ соціального статусу та репутації в суспільстві. Суть поваги людської гідності полягає у можливості самореалізуватися особистості, поважати власні моральні принципи та етичні кодекси, підтримувати повагу інших, державних установ та їх посадових і службових осіб, а також здатність вимагати будь-якої поваги щодо етичних якостей та етичних принципів від інших людей [1]. Реалізація заснована на міжнародній стандартній гарантії цього права в країні. Відповідно до нової статті 151-1 Кримінального кодексу України правопорушник своїми діями ганьбить на принижує честь та гідність людини. Відповідне положення про повагу честі і гідності закріплено багатьма міжнародно-правовими актами та Основним законом України - Конституцією. По-перше, Загальна декларація прав людини передбачає право на повагу людської гідності: «Усі люди народжуються вільнили і рівнили в своїй гідності і правах. Вони наділені розумом і совістю і повинні вчиняти по відношенню один до одного у дусі братства» (ст. 1) [2]. Конституція України фіксує це право у ст. 3: «Людина, їі життя $і$ здоров’я, честь i гідність, недоторканність і безпека визнаються в Україні найвищою соціальною иінністю. Права і свободи людини та їх гарантії визначають зміст і спрямованість діяльності держави» [3].

Відповідно до змін Кримінальний кодекс України доповнюється новою статтею 151-1. Стаття містить положення, які вводять в кримінальне законодавство такий термін, як «наклеп». Наклеп, тобто умисне поширення завідомо недостовірних відомостей, що ганьблять честь і гідність іншої особи [4]. Треба звернути увагу на те, що наклеп - умисний злочин. Тобто особу можна звинуватити в наклепі, якщо вона не просто розповсюдила якусь недостовірну інформацію, що порочить честь і гідність, а зробила це з конкретною метою - зганьбити честь і гідність конкретної особи. Відсутність такого наміру в ідеальних умовах повинно вести до закриття кримінального провадження.

Важливо, що, згідно з поправками до статті 477 Кримінального процесуального кодексу (КПК) України, кримінальне провадження про наклеп віднесено до проваджень форми приватного обвинувачення, тобто може бути відкрито слідчим, прокурором виключно на підставі заяви потерпілого від такого злочину. Отже, обов'язковою умовою притягнення до відповідальності за наклеп є наявність реального потерпілого, який хоче встановити справедливість. Це великий плюс з точки зору захисту, оскільки це дозволить в повному обсязі застосовувати таку процедуру, як примирення з потерпілим.

Звертаємо увагу на те, що наклеп відноситься до злочинів невеликої тяжкості і термін притягнення до відповідальності становить відповідно два роки 3 дня вчинення або три - якщо йдеться про злочин, передбачений частиною 3 статті 151-1 КК України. 
Але повернемося до складу злочину. У ньому криються як небезпека бути залученими за необдумані слова, так і основні аргументи на захист від такого звинувачення.

Отже, за наклеп наступає відповідальність коли поширюються недостовірні відомості, що ганьблять честь і гідність іншої особи. Тобто якщо недостовірні відомості не будуть паплюжити честь та гідність, відповідальність за їх поширення наступити не може.

Що ж стосується недостовірності, то в цивільних правовідносинах на Україні діє презумпція недостовірності будь-якої негативної інформації. Так, згідно з частиною 3 статті 277 Цивільного кодексу (ЦК) України, негативна інформація, поширена про особу, вважається недостовірною, якщо особа, ї̈ поширила, не доведе протилежного.

Однак це не означає, що будь-яка негативна слово, сказане на адресу якоїсь особи, матиме наслідком заяву про злочин. Адже в кримінальному праві діє, по-перше, презумпція невинуватості, а значить, саме заявнику і слідчому треба буде шукати підтвердження недостовірності поширеної інформації. По-друге, кримінальне право не допускає аналогії. А тому, щоб засудити кривдника за кинуте на адресу особи слово «дурень», саме потерпілому треба буде пройти медичне обстеження, яке підтверджує відсутність відставання в розумовому розвитку. В продовження думки - якщо наклеп полягає в тому, що певній особі належать сумнівного походження багатства, йому доведеться відкрити власні банківські рахунки, інформацію про майно та джерела доходів. Особливо цікавим було виробництво за частиною 3 статті 151-1 КК України, коли в рамках одного кримінального провадження особі доведеться доводити нескоєння ним іншого, тяжкого або особливо тяжкого, злочину.

Це, загалом, дає надію, що заяви про наклеп не набудуть масового характеру, а подавати їх будуть тільки ті, чиї права дійсно порушені. Та ще й з можливістю подати цивільний позов у кримінальному провадженні без сплати судового збору, який в частині вимог про відшкодування моральної шкоди, заподіяної честі, гідності та ділової репутації особи, досягає $10 \%$ від суми позову.

Що ж стосується захисту від обвинувачення в наклепі, то сторона захисту не обмежена в можливостях доведення. Тому можна і потрібно використовувати положення Закону України «Про інформацію» щодо обмеженої відповідальності за поширення інформації - закон не обмежує норми статей 29 і 30 цього Закону якимось одним видом юридичної відповідальності. Навпаки, стаття 27, «вступна» до розділу про відповідальність за поширення інформації, вказує на те, що положення розділу IV поширюються на всі види відповідальності.

Нагадаємо, що через положення статті 29 Закону «Про інформацію» інформація з обмеженим доступом може бути поширена, якщо вона є суспільно необхідною, тобто предметом громадського інтересу, і право громадськості знати цю інформацію переважає над потенційною шкодою від іï поширення [5].

Щоправда, відповідно до Закону від 28 січня 2014 року № 732-VII (732-18), Закон від 16 січня 2014 року № 721-VII, що вводить кримінальну відповідальність за наклеп був визнаний таким, що втратив чинність, і дотепер таке явище як наклеп 
повністю відсутне в кримінальному праві України. Найбільш приближеним до терміна «наклеп» $є$ поширення недостовірної інформації та поширення неправдивих чуток. Перший термін вживається уже в цивільному праві, регулюється статтею 277 Цивільного кодексу України, і за поширення недостовірної інформації про фізичну або юридичну особу може настати цивільна відповідальність. Якщо ж у процесі судового розгляду поширювач неправдивої інформації заявляє, що це його суб'єктивна думка щодо певної людини або оціночне судження і вони були поширені в досить брутальній або грубій формі, то людина, яка вважає, що оціночне судження принижує їі честь, гідність чи ділову репутацію, має повне право звернутися до суду з клопотанням про відшкодування моральної шкоди. Другий термін «поширення неправдивих чуток» регулюється статтею 173-1 Кодексу України про адміністративні правопорушення, ця стаття дещо різниться від уже недіючої статті КК України 151-1 та статті 277 ЦК України, адже в ній з'являється така підстава, коли поширення цих неправдивих чуток може викликати паніку серед населення або порушення громадського порядку, тому цю норму права рідко застосовують щодо правопорушників, які розповсюдили неправдиву інформацію про конкретну особу.

\section{Jimepamypa}

1. Приватне життя і поліція. Концептуальні підходи. Теорія та практика. / відп. ред. Ю.І. Римаренко. Київ : КНТ, 2006. 740 с.

2. Всеобщая декларация прав человека / Международные акты о правах человека. Сборник документов. Москва : Издательская группа НОРМА ИНФРА, 1999.

3. Конституція України. URL: https://zakon.rada.gov.ua/laws/show $/ 254 \% \mathrm{D} 0 \% \mathrm{BA} / 96 \% \mathrm{D} 0 \%$ B2 $\%$ D1\% 80\#Text.

4. Закон України № 721-VII від 16 січня 2014 року «Про внесення змін до Закону України «Про судоустрій і статус суддів» та процесуальних законів щодо додаткових заходів захисту безпеки громадян». Урядовий кур’єр. 21 січня 2014 року, вівторок, № 11 URL: http://ukurier.gov.ua/media/ documents/2014/01/20/721-V\% D0\% 86\% D0\% 86.pdf.

\section{Анотація}

Романова А. Є., Чернявський П. В., Соколова І. О. Відповідальність за наклеп (дифамацію) в Україні та країнах світу. - Стаття.

Проблема дифамації, iї нормативного оформлення, доведення й боротьби з нею у вітчизняному й зарубіжному науковому дискурсі була і $є$ актуальною для розгляду.

Метою статті є дослідження відповідальності за наклеп і дифамацію станом на сьогодні в різних країнах світу та нашій із вами Батьківщині. Також у статті зроблено спробу дослідити питання дифамації в контексті можливості запровадження цього інституту в Україні на основі аналізу розвитку закордонних тенденцій цієї галузі права.

Незважаючи на те, що законодавчо термін «дифамація» в Україні не закріплений, останнім часом це явище дедалі частіше трапляється в українському суспільстві та становить загрозу демократичному ладу. Зважаючи на підвищену увагу до теми поваги репутації та збереження позивного іміджу публічних осіб серед населення, вважаємо за доцільне розглянути таку правову категорію, як «дифамація».

Дифамація - це міжнародний правовий термін, який закріплено в законодавстві багатьох країн світу та який використовується як узагальнюючий щодо різних видів порушень особистих немайнових прав на захист честі, гідності, репутації й доброго імені.

У багатьох країнах дифамація підлягає переслідуванню як в цивільному, так і в кримінальному порядку. Специфіка такого переслідування витікає з відмінностей між цивільним і кримінальним правом у розвинених правових системах світу. Поняття «законодавство про дифамацію» зазвичай включає в себе всі закони, які захищають репутацію і честь громадян. Такі закони оперують широким спектром понять, а саме: приниження гідності, наклеп, образа й та інше. 
у зв'язку з наведеним актуальним є визначення сутності дифамації, відповідальності за неї, відшукання балансу між свободою слова та захистом репутації громадян. ності.

Ключові слова: дифамація, поширення неправдивої інформації, недостовірність, захист честі і гід-

\section{Summary}

Romanova A. E., Chernyavsky P. V., Sokolova I. O. Responsibility for defamation in Ukraine and the world. - Article.

The problem of defamation, its normative design, proof and struggle against it in domestic and foreign scientific discourse was and is relevant for consideration.

The aim of the article is to study the responsibility for slander and defamation, as of today, in different countries of the world and our homeland. The article also attempts to investigate the issue of defamation in the context of the possibility of introducing this institution in Ukraine based on the analysis of the development of foreign trends in this area of law.

Despite the fact that the term "defamation" is not enshrined in law in Ukraine, this phenomenon has recently become more common in Ukrainian society and poses a threat to democracy. Given the increased attention to the topic of respect for the reputation and preservation of the call sign of public figures among the population, we consider it appropriate to consider such a legal category as "defamation".

Defamation is an international legal term that is enshrined in the laws of many countries around the world and is used as a generalization of various types of violations of personal non-property rights to protect honor, dignity, reputation and reputation.

In many countries, defamation is subject to both civil and criminal prosecution. The specificity of such persecution stems from the differences between civil and criminal law in the developed legal systems of the world. The concept of "defamation law" usually includes all laws that protect the reputation and honor of citizens. slander, insult, etc.

In connection with the above, it is important to determine the essence of defamation, responsibility for it, finding a balance between freedom of speech and protection of the reputation of citizens.

Key words: defamation, dissemination of false information, unreliability, protection of honor and dignity. 